\title{
Effect of Indoor and Underground Storage on Efficient Vegetative Propagation of Dwarf Napier Grass (Pennisetum purpureum Schumach)
}

\author{
Yusuke Iki', Yasuyuki Ishii ${ }^{*}$, Satoru Fukagawa ${ }^{3}$, Sachiko Idota ${ }^{2}$ \\ ${ }^{1}$ Graduate School of Agriculture, University of Miyazaki, Miyazaki, Japan \\ ${ }^{2}$ Faculty of Agriculture, University of Miyazaki, Miyazaki, Japan \\ ${ }^{3}$ Nagasaki Agricultural and Forestry Technical Development Center, Shimabara, Japan \\ Email: "yishii@cc.miyazaki-u.ac.jp
}

Received 11 April 2016; accepted 28 May 2016; published 1 June 2016

Copyright (C 2016 by authors and Scientific Research Publishing Inc.

This work is licensed under the Creative Commons Attribution International License (CC BY). http://creativecommons.org/licenses/by/4.0/

(c) (i) Open Access

\begin{abstract}
Dwarf, late-heading (DL) Napier grass is suitable for both cut-and-carry and grazing management due to sufficient yield and quality potential. This species can hardly produce viable seed, and thus vegetative propagation should be essential before winter in temperate regions of southern Kyushu. The objective of this study was to determine the efficient storage methods of DL vegetative propagation. Two experiments were carried out, the first focused on indoor storage of 10-node stem sections under room- or chilling $\left(10^{\circ} \mathrm{C}\right)$ conditions and the second, on underground storage of ten-node and one-node stem sections at $10 \mathrm{~cm}, 25 \mathrm{~cm}$ or $40 \mathrm{~cm}$ depth. After both storages, both of ten-node stem sections, cut into single nodes, and one-node stem sections were transplanted into the soil and counted for the emergence every month in 3 months of planting. In indoor-storage, while storage temperature hardly affected the emergence $(P>0.05)$, storage period significantly reduced the emergence percentage. In underground storage, while one-node storage achieved constantly $60 \%$ emergence, ten-node storage achieved a higher emergence at $80 \%$ under $25-\mathrm{cm}$ and $40-\mathrm{cm}$ depths. The results of the study suggest that underground storage of longer stem sections at $25 \mathrm{~cm}$ depth could be applied to practical vegetative propagation in the region.
\end{abstract}

\section{Keywords}

Vegetative Propagation, Temperature, Storage, Stem Section, Dwarf Napier Grass

\footnotetext{
${ }^{*}$ Corresponding author.
}

How to cite this paper: Iki, Y., Ishii, Y., Fukagawa, S. and Idota, S. (2016) Effect of Indoor and Underground Storage on Efficient Vegetative Propagation of Dwarf Napier Grass (Pennisetum purpureum Schumach). American Journal of Plant Sciences, 7, 1173-1179. http://dx.doi.org/10.4236/ajps.2016.78112 


\section{Introduction}

Japanese animal husbandry has developed significantly based on an imported feed supply. However, serious problems such as the danger of animal infectious diseases, lower feed sufficiency ratio and the treatment of animal wastes have led to the increasing importance of sustainable self-sufficient herbage production by improving cropping system [1]. Napier grass (Pennisetum purpureum Schumach) has high dry matter productivity and can overwinter in the border between subtropical and temperate zones such as in Florida, USA [2] and low-altitude sites of southern Kyushu, Japan [3]. In particular, dwarf, late-heading (DL) Napier grass has a high leaf percentage [4] with a sufficient combination of yielding ability and forage quality, and can be applied to cut-and-carry and grazing uses [5]. Therefore, this genotype is promising to be useful for small-scale Japanese Black beef cow producers. However, this grass species rarely produces viable seed, so it must be propagated vegetatively by efficient storage methods for nursery plants [6] during the wintering season, contrary to the sward renewal methods in seed-propagated plants [7]. Recently, a cell-tray propagation method was established [8], although it should be managed in a glasshouse during the wintering season [9]. Therefore, this study was aimed at determining the emergence of nodal cuttings under several storage methods to establish labor-saving, efficient nursery storage methods during the winter.

\section{Materials and Methods}

Dwarf, late-heading (DL) Napier grass (Pennisetum purpureum Schumach), which was derived from Florida, USA via Thailand [4], was grown on Andosol at Kibana Agricultural Research Station, Faculty of Agriculture, University of Miyazaki, Japan ( $31^{\circ} 50^{\prime} \mathrm{N}$ and $131^{\circ} 25^{\prime} \mathrm{E}, 31 \mathrm{~m}$ asl). Assessment of temperature conditions in the wintering period was conducted from 26 December, 2013 to 25 June, 2014 (Experiment 1), and assessment of underground storage conditions was from 9 December, 2014 to 3 June, 2015 (Experiment 2). Stem sections in both experiments were cut at $10 \mathrm{~cm}$ above the soil and were sampled from nodes which had dead leaves, a symptom of maturity.

\subsection{Effect of Temperature on Emergence of Stem Sections (Experiment 1)}

Ten stems possessing ten nodes each were stored in a plastic container $(9.3 \mathrm{~L})$ with a dehumidifying agent (Okamoto Ltd., Tokyo, Japan) at two temperatures, room temperature (RT, average of $14^{\circ} \mathrm{C}$ ) and low temperature (LT, regulated at $10^{\circ} \mathrm{C}$ in a refrigerator) for $0,1,2,3$ and 4 months, kept in dark. After the storage period, stem parts were cut into one node and transplanted perpendicularly into cell trays $(3.0 \mathrm{~cm} \times 3.0 \mathrm{~cm} \times 4.5 \mathrm{~cm}$ high) filled with culture soil for raising seedlings (Takii Co. Ltd., Kyoto, Japan) at 10 replications. The cell trays were placed in a glasshouse without regulating air temperature and watered depending on growth conditions. The emergence of nursery plants was counted at every node position acropetally at $0,1,2$ and 3 months after bedding. The emergence percentage at 3 months after bedding was defined as the established percentage of nursery plants. The temperature during storage was monitored using a thermometer (Thermoleaf, Taisei $\mathrm{E}$ and $\mathrm{L}$ Ltd., Tokyo, Japan). The mean temperature in the RT treatment was $14^{\circ} \mathrm{C}$, the maximum was $16^{\circ} \mathrm{C}$ and the minimum was $12^{\circ} \mathrm{C}$, in contrast to $\mathrm{LT}$, where the average was $10^{\circ} \mathrm{C}$, the maximum was $10.5^{\circ} \mathrm{C}$ and the minimum was $9.4^{\circ} \mathrm{C}$.

\subsection{Effect of Underground Storage Conditions on Emergence of Stem Sections (Experiment 2)}

Ten-node stem sections and one-node stem sections of dwarf Napier grass were stored horizontally at three depths, $10 \mathrm{~cm}, 25 \mathrm{~cm}$ and $40 \mathrm{~cm}$, in Andosol with three replications on 9 December 2014. When the stored stem sections were dug out on 7 April 2015, the ten-node stem sections were cut into individual nodes, and all singlenode stem sections from both treatments were transplanted perpendicularly into Andosol. The emergence of nursery plants was counted at $0,1,2$ and 3 months after planting, and the emergence percentage at 3 months after planting was defined as the established percentage of nursery plants. The temperature was monitored using a thermometer. The average temperature was $9.6^{\circ} \mathrm{C}$ at a depth of $10 \mathrm{~cm}, 10.9^{\circ} \mathrm{C}$ at $25 \mathrm{~cm}$, and $12.3^{\circ} \mathrm{C}$ at $40 \mathrm{~cm}$. In the experimental period, the mean 10-day air temperature was $9.9^{\circ} \mathrm{C}$, with a maximum of $13.5^{\circ} \mathrm{C}$ in mid- and late March and a minimum of $5.7^{\circ} \mathrm{C}$ in early February.

As for the nursery production steps, the labor time was conducted to record after defoliation by sickle with 
three replications, engaging two persons. Production steps were from cutting of single-node which has a tiller bud positioned on matured nodes attached with dead leaves by scissors, digging hole, burying stem sections before wintering, to digging out and transplanting of stem sections to Andosol after wintering.

\subsection{Statistical Analysis}

Analysis of variance was performed using Excel Statistics (OMC Co. Ltd., Saitama, Japan). Differences in mean values were assessed at the $5 \%$ probability level using least significant difference (LSD) method.

\section{Results}

\subsection{Effect of Temperature on Emergence of Stem Sections (Experiment 1)}

In Experiment 1, temperature (LT or RT) did not affect the emergence percentage of nursery plants $(P>$ 0.05). A longer storage period significantly reduced the emergence percentage at both temperatures, leading to nil emergence after 4 months of storage (Figure 1).

\subsection{Effect of Underground Storage Conditions on Emergence of Stem Sections (Experiment 2)}

In Experiment 2, one-node storage led to a constant emergence percentage of nursery plants of around 60\% at every storage depth up to 2 months of bedding (Figure 2(a)). Ten-node storage led to a higher emergence percentage of around $80 \%$ at every planting depth, while nodes stored at a 10 -cm depth had a significantly lower emergence percentage after 3 months of bedding than the other depths. For storage of both one- and ten-node cuttings, a 25-cm depth led to a stable percentage of nursery plant emergence among months from bedding (Figure 2). Underground temperatures in the present study did not drop below $5^{\circ} \mathrm{C}$, leading to a high emergence percentage of nursery plants.

The labor time required for the total production steps from cutting stem nodes before wintering to transplanting them to Andosol increased as the depth increased from 10 to $40 \mathrm{~cm}$, since the difference in labor time of digging holes and digging out plants across different depths led to a smaller labor time for the 10-cm depth than the other depths (Table 1). Compared with 10-node stem section, one node stem section required smaller labor time across all depths.

\section{Discussion}

Some herbaceous plants can be propagated from cuttings [10]. It is so common to use rooting hormone to the base of the cutting for herbaceous plant propagation, however, no plant hormone was necessary for rooting from cuttings in the present study of DL Napier grass as well as in woody fruit tree of Grewia coriacea [11]. Inanaga et al. [12] showed that Napier grass stem nodes can be stored underground in the wintering period when the minimum temperature is maintained above $5^{\circ} \mathrm{C}$, if stem nodes were cut without stress suffered from subzero air temperatures. The cuttings in Napier grass should be 2 - 10 nodes long to maintain a high

Table 1. Labor time (min) of steps in nursery plant production of dwarf Napier grass in one-node and ten-node stem sections under different winter storage (mean \pm standard deviation, $\mathrm{n}=3$ ).

\begin{tabular}{cccccccc}
\hline \multirow{2}{*}{ Production step } & \multicolumn{3}{c}{ One-node stem section } & \multicolumn{3}{c}{ Ten-node stem section } \\
\cline { 2 - 7 } & $10 \mathrm{~cm}$ & $25 \mathrm{~cm}$ & $40 \mathrm{~cm}$ & $10 \mathrm{~cm}$ & $25 \mathrm{~cm}$ & $40 \mathrm{~cm}$ \\
\hline Stem-node cutting & $4.3 \pm 0.3$ & $4.0 \pm 0.7$ & $4.4 \pm 0.6$ & $5.0 \pm 1.0$ & $5.3 \pm 0.6$ & $5.2 \pm 0.5$ \\
Digging hole & $1.5 \mathrm{a} \pm 0.8$ & $2.4 \mathrm{a} \pm 0.4$ & $4.5 \mathrm{~b} \pm 0.6$ & $1.6 \mathrm{a} \pm 1.0$ & $2.1 \mathrm{a} \pm 0.6$ & $4.0 \mathrm{~b} \pm 0.4$ \\
Burying stem sections & $1.2 \pm 0.5$ & $1.9 \pm 0.5$ & $1.8 \pm 0.2$ & $1.6 \pm 0.4$ & $1.6 \pm 0.4$ & $3.8 \pm 1.5$ \\
Digging-out and transplanting of stem sections & $3.2 \pm 0.6$ & $3.3 \pm 0.7$ & $4.4 \pm 0.3$ & $12.8 \pm 4.4$ & $12.9 \pm 0.6$ & $13.4 \pm 1.9$ \\
Total & $10.2 \mathrm{a} \pm 0.6$ & $11.7 \mathrm{a} \pm 1.5$ & $15.1 \mathrm{~b} \pm 1.4$ & $21.0 \pm 4.9$ & $21.9 \pm 0.3$ & $26.4 \pm 3.6$ \\
\hline
\end{tabular}

Figures with different letters denote significant difference at the $5 \%$ level by LSD method. 


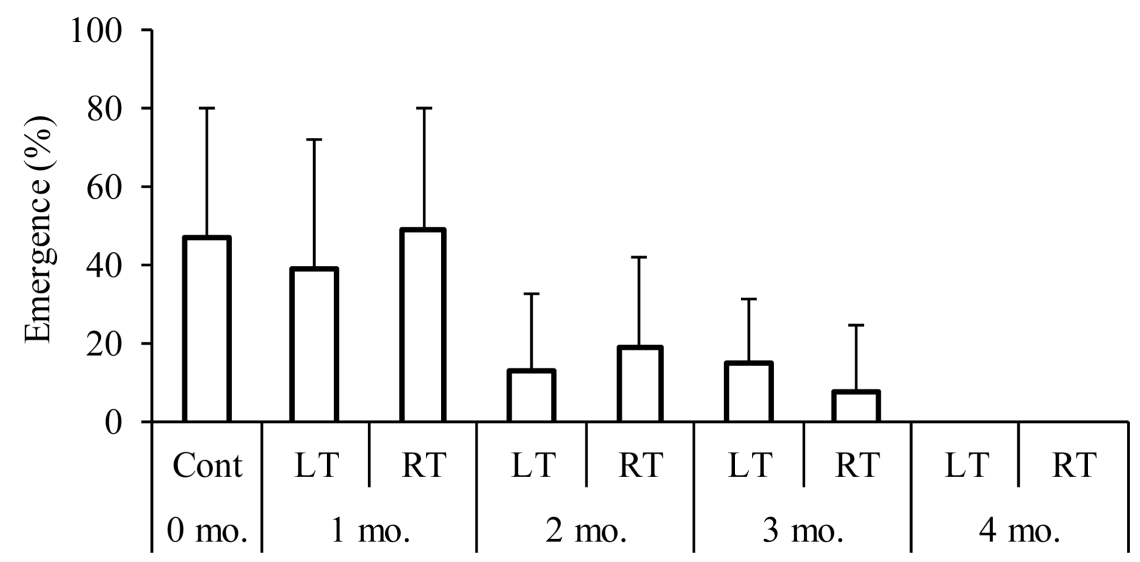

Storage time and temperature

(a)

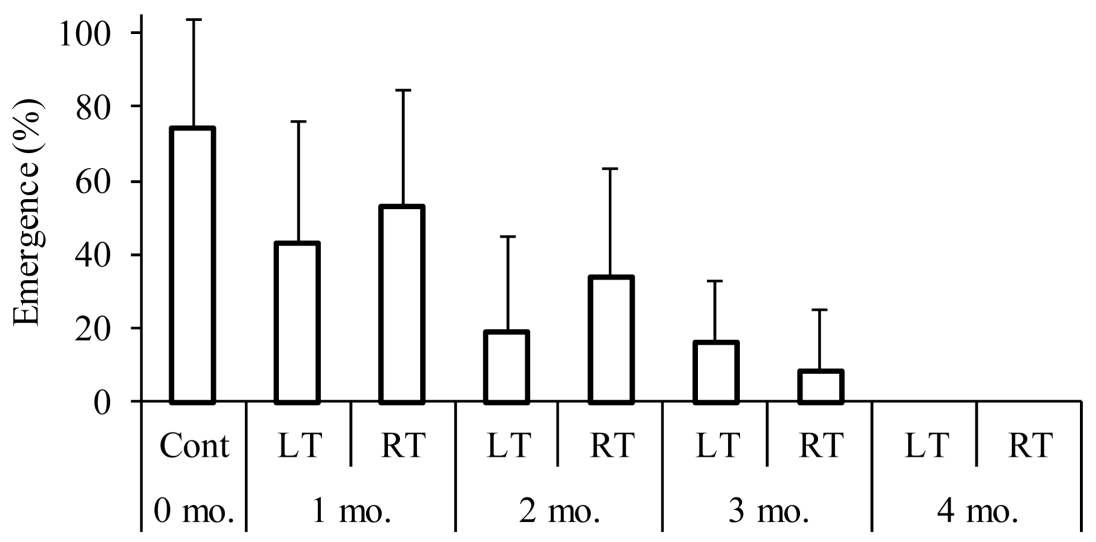

Storage time and temperature

(b)

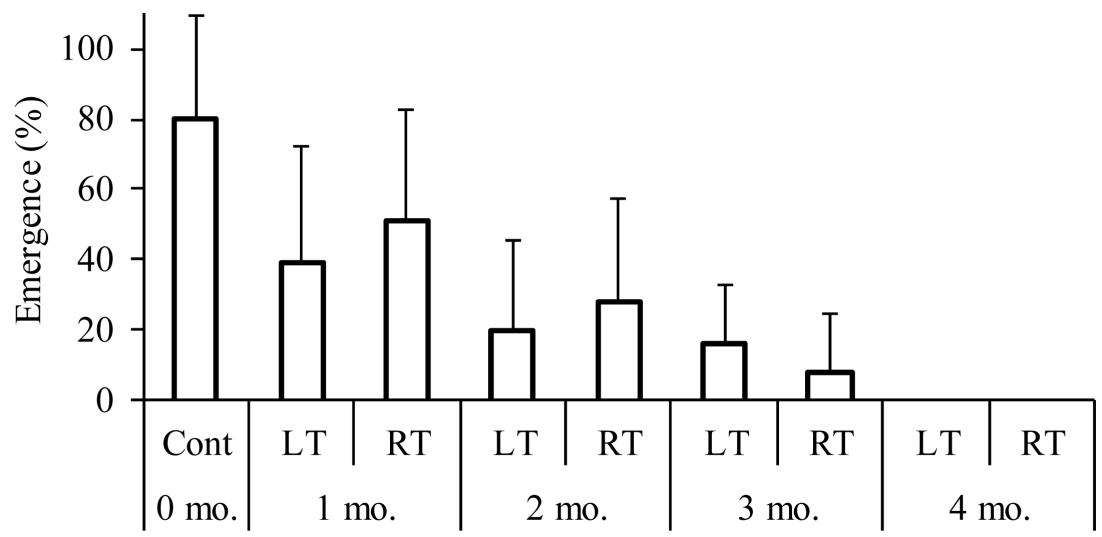

Storage time and temperature

(c)

Figure 1. Effect of storage period and temperature on the emergence of nursery plants derived from stem sections of dwarf Napier grass with a bedding period of (a) 1 month, (b) 2 months and (c) 3 months in a glasshouse (mean \pm standard deviation, $\mathrm{n}=10$ ). Storage temperature: LT (low temperature at $10^{\circ} \mathrm{C}$ ), $\mathrm{RT}$ (room temperature averaging $14^{\circ} \mathrm{C}$ ). Cont $=$ control. 


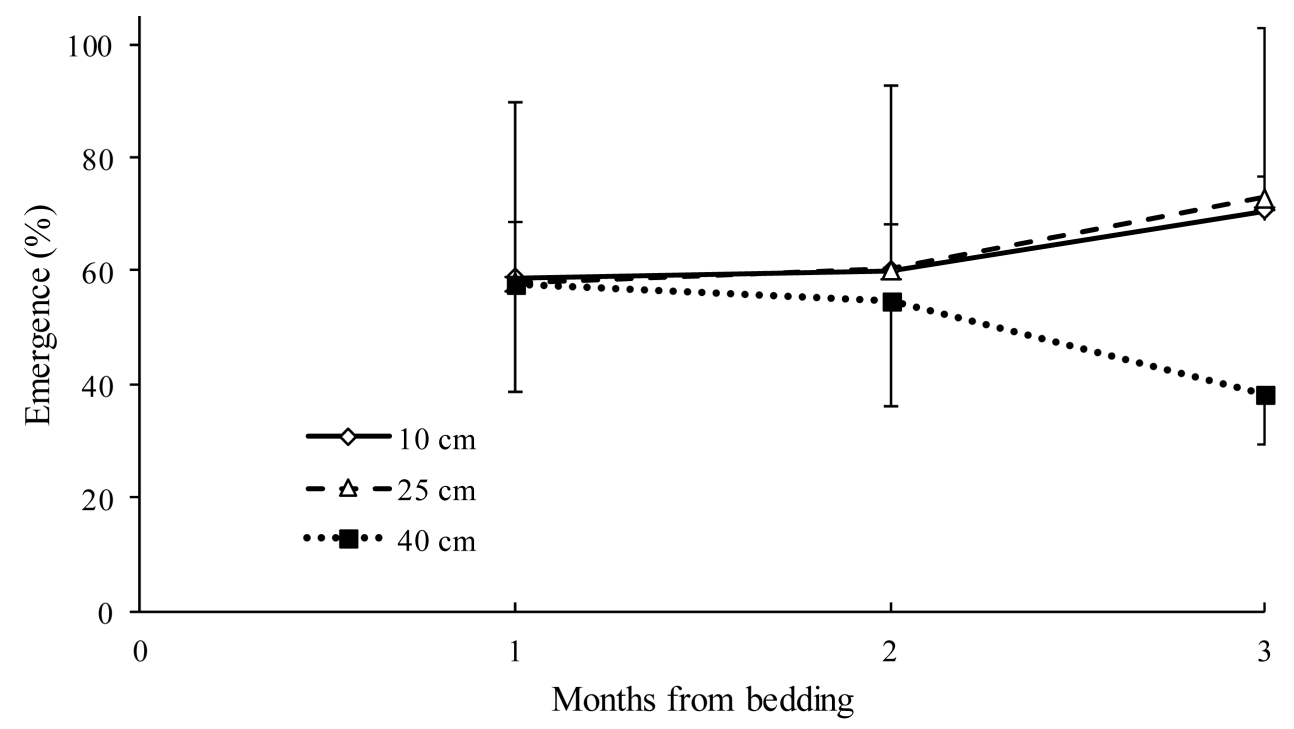

(a)

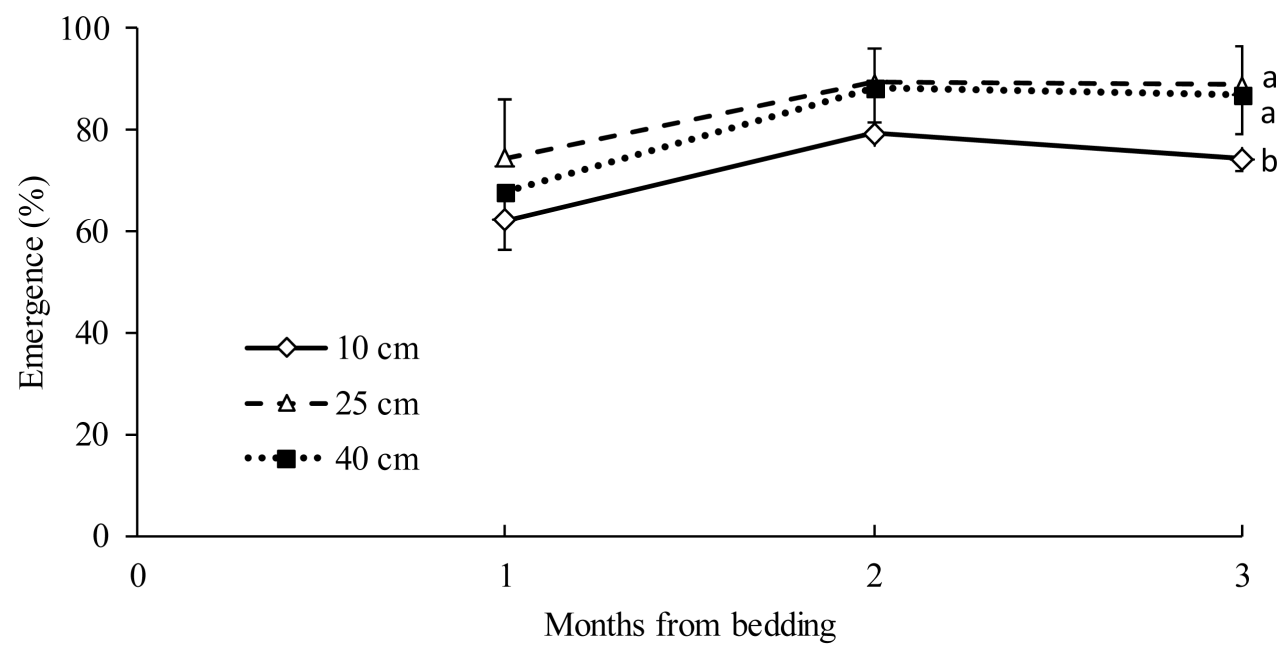

(b)

Figure 2. Effect of storage depth in soil on emergence of nursery plants with a bedding period from (a) oneand (b) ten-node stem sections of dwarf Napier grass plants (mean \pm standard deviation, $n=10$ ). Figures with different letters denote significant difference at the $5 \%$ level by LSD method.

emergence [6], since single-node cuttings must be planted deeper than longer cuttings, which is consistent with the present study, showing for the higher emergence percentage in ten-node than in single-node cuttings.

Even though the temperature conditions in Experiment 1 at $10^{\circ} \mathrm{C}$ and $14^{\circ} \mathrm{C}$ for $\mathrm{LT}$ and $\mathrm{RT}$, respectively, were not very different from those in Experiment 2 in a range of $9.6^{\circ} \mathrm{C}, 10.9^{\circ} \mathrm{C}$ and $12.3^{\circ} \mathrm{C}$ for $10 \mathrm{~cm}, 25 \mathrm{~cm}$ and $40 \mathrm{~cm}$ depth, respectively, the steady decrease in the emergence percentage of nursery plants with storage period in Experiment 1 might be due to factors other than temperature. In the present study, LT condition was planned to suppress fungal growth [13] on stem cuttings, while some symptom of fungal damage appeared even at LT in Experiment 1, in contrast with less damage in the underground soil storage for Experiment 2, probably due to the interaction of pathogenic fungi and overwintering plants [14]. No observations were made of stem moisture in the present study, although stems stored in plastic containers appeared to dehydrate during storage, in contrast to the maintenance of stem moisture during underground storage in Experiment 2. The emergence percentage of nursery plants from 10-node stem sections stored at depths of 
$25 \mathrm{~cm}$ and $40 \mathrm{~cm}$ was as high as $80 \%$ of that under the control conditions ( 0 months of storage in Experiment 1 ), suggesting for the potential emergence for 4 months of underground storage. Drop in emergence percentage from 2 months to 3 months of bedding at $40 \mathrm{~cm}$ depth in both length of stem cuttings appeared to be reflected by the humid soil moisture for 4 months of underground storage, which might reduce the vitality of tiller buds and failed to be established by seedlings with the increase in temperature and evaporation pressure [15].

In the ecological aspects, belowground bud bank of $C_{3}$ caespitose grasses plays the key issue for genet persistence in the mixed-grass swards [16]. In $\mathrm{C}_{4}$ Napier grass, artificial underground storage of tiller buds by cuttings should possess the efficient and labor-saving propagation method in the region examined. While indoor storage has a merit for independence of soiling media during storage, maintenance of stem moisture during storage is necessary to be improved so as to increase the emergence percentage of stem cuttings.

\section{Conclusion}

In the present study, storage of longer stem sections at a $25-\mathrm{cm}$ soil depth for 4 months during wintering period could be applied to practical vegetative storage methods in a good combination of higher emergence and smaller labor time in southern Kyushu, Japan. However, indoor storage needs modification to maintain stem moisture and suppress fungal growth during several months of storage.

\section{Acknowledgements}

This work was partly supported by grants-in-aid for scientific research from the Japan Society from the Promotion of Science (JSPS Kiban Research-(C) No. 25450025).

\section{References}

[1] Kanno, T., Morita, S., Sasaki, H. and Nishimura, K. (2014) Recent Situation and Future Prediction for Areas Suitable for Double Cropping of Corn (Zea mays L.) Production in Japan's Kanto Region. Japanese Journal of Grassland Science, 60, 161-166. https://www.jstage.jst.go.jp/article/grass/60/3/60_161/_pdf

[2] Na, C., Sollenberger, L.E., Erickson, J.E., Woodard, K.R., Vendramini, J.M.B. and Silveira, M.L. (2015) Management of Perennial Warm-Season Bioenergy Grasses. I. Biomass Harvested, Nutrient Removal, and Persistence Responses of Elephantgrass and Energycane to Harvest Frequency and Timing. Bioenergy Research, 8, 581-589. http://dx.doi.org/10.1007/s12155-014-9541-6

[3] Ishii, Y., Ito, K. and Fukuyama, K. (2000) Effect of Several Cultivation Factors on the Overwintering Ability of Napiergrass in the Southern Kyushu. Japanese Journal of Crop Science, 69, 209-216. https://www.jstage.jst.go.jp/article/jcs1927/69/2/69_2_209/_pdf http://dx.doi.org/10.1626/jcs.69.209

[4] Mukhtar, M., Ishii, Y., Idota, S. and Sonoda, T. (2003) Dry Matter Productivity and Overwintering Ability in the Dwarf and Normal Napier Grasses as Affected by the Planting Density and Cutting Frequency. Plant Production Science, 6, 65-73.

http://ci.nii.ac.jp/els/110001720479.pdf?id=ART0001844283\&type=pdf\&lang=ip\&host=cinii\&order_no=\&ppv_type= 0\&lang $\mathrm{sw}=\& \mathrm{no}=1460213883 \& \mathrm{cp}=$ http://dx.doi.org/10.1626/pps.6.65

[5] Ishii, Y., Hamano, K., Kang, D.J., Rengsirikul, K., Idota, S., Fukuyama, K. and Nishiwaki, A.(2013) C.-Napier Grass Cultivation for Cadmium Phytoremediation Activity and Organic Livestock Farming in Kyushu, Japan. Journal of Agricultural Science and Technology A, 3, 321-330. http://www.davidpublishing.com/davidpublishing/Upfile/5/21/2013/2013052100373995.pdf

[6] Knoll, J.E. and Anderson, W.F. (2012) Vegetative Propagation of Napier Grass and Energy Cane for Biomass Production in the Southeastern United States. AgronomyJournal, 104, 518-522. http://dx.doi.org/10.2134/agronj2011.0301

[7] Creighton,P., Kennedy, E., Hennessy, D. and O’Donovan, M. (2016) Impacts of Sward Renewal Method with Perennial Ryegrass (Lolium perenne) on Dry Matter Yield, Tiller Density and Nitrate Leaching. American Journal of Plant Sciences, 7, 684-694. http://dx.doi.org/10.4236/ajps.2016.74061

[8] Yamano, A., Ishii, Y., Mori, K., Utamy R.F. and Idota, S. (2011) Effect of Density of Mother Plants on Efficiency of Nursery Production in Dwarf Napier Grass (Pennisetum purpureum Schumach). Proceedings of the 7th Asian Crop Science Conference, Bogor, 345-348.

http://www.cropscience.jp/acsa/conference/Proceeding-ACSAC-ISBN.pdf\#search='Proceedings + of + the +7 th + Asian $+\mathrm{C}$ 
$\underline{\text { rop+Science+Conference\%2C+Bogor\%2C+Indonesia' }}$

[9] Utamy, R.F., Ishii, Y., Idota, S., Khairani, L. and Fukuyama, K. (2016) Development of Mechanical Methods for Cell-Tray Propagation and Field Transplanting of Dwarf Napier Grass (Pennisetum purpureum Schumach.). Journal of Agriculture for Rural Development in the Tropics and Subtropics, 117, 11-19.

http://www.jarts.info/index.php/jarts/article/view/2015112649437

[10] Guse, W.E. (2001) Propagating Herbaceous Plants from Cuttings. A Pacific Northwest Extension Publication, PNW 151, Washington DC, 1-7. http://4h.wsu.edu/em2778cd/pdf/pnw0151.pdf\#search='Propagating+Herbaceous+Plants+from+Cuttings'

[11] Mercier, B.A., Attibayéba, Pierre, K.J., Léon, N. and Fidèle, M. (2009) Propagation by Cutting of Grewia coriacea Mast. (Malvaceae). Pakistan Journal of Biological Sciences, 19, 36-42. http://dx.doi.org/10.3923/pjbs.2016.36.42

[12] Inanaga, S., Ito, K., Yajima, T., Inoue, H. and Hatano, S. (1990) Effect of Temperature on Viability and Elongation of Lateral Bud of Napier Grass (Pennisetum purpureum Schumach). Japanese Journal of Crop Science, 59, 747-751. https://www.jstage.jst.go.jp/article/jcs1927/59/4/59_4_747/_pdf http://dx.doi.org/10.1626/jcs.59.747

[13] Wang, Y., Bao, Z., Zhu, Y. and Hua, J. (2015) Analysis of Temperature Modulation of Plant Defense against bIotrophic Microbes. Molecular Plant-Microbe Interactions, 22, 498-506.

http://apsjournals.apsnet.org/doi/pdf/10.1094/MPMI-22-5-0498 http://dx.doi.org/10.1094/MPMI-22-5-0498

[14] Griffith, M. and Yaish, M.W.F. (2004) Antifreeze Proteins in Overwintering Plants: A Tale of Two Activities. Trends in Plant Science, 9, 399-405. http://dx.doi.org/10.1016/j.tplants.2004.06.007

[15] Will, R.E., Wilson, S.M., Zou, C.B. and Hennessey, T.C. (2013) Increased vapor Pressure Deficit Due to Higher Temperature Leads to Greater Transpiration and Faster Mortality during Drought for Tree Seedlings Common to the Forest-Grassland Ecotone. New Phytologist, 200, 366-374. http://dx.doi.org/10.1111/nph.12321

[16] Ott, J.P. and Hartnett, D.C. (2015) Bud-Bank and Tiller Dynamics of Co-Occurring $C_{3}$ Caespitose Grasses in MixedGrass Prairie. American Journal of Botany, 102, 1642-1671. http://dx.doi.org/10.3732/ajb.1500039 